\title{
Endocrine differences in rams after genetic selection for testis size
}

\author{
J. R. McNeilly, M. Fordyce, R. B. Land, G. J. Lee and R. Webb \\ A.F.R.C. Animal Breeding Research Organisation, Dryden Laboratory, Roslin, \\ Midlothian EH25 9PS, U.K.
}

\begin{abstract}
Summary. Testis diameter and body weight were recorded from 6 to 76 weeks of age in ram lambs from two established lines selected for high $(\mathrm{H})$ and low $(\mathrm{L})$ testis size. While testis growth was greater in the $\mathrm{H}$ line up to 14 weeks of age $(P<0.001)$, body weight was significantly lower, with the L line rams being $10 \mathrm{~kg}$ heavier by 76 weeks. There were no differences in plasma LH up to 20 weeks of age, but FSH concentrations were significantly lower at 14 and 20 weeks in the $\mathrm{H}$ line. Testosterone concentrations were not significantly higher in the $\mathrm{H}$ line from 6 to 20 weeks. In lambs castrated at birth, significantly higher FSH values were recorded from 6 to 20 weeks of age in the $\mathrm{H}$ line $(P<0.001)$ whereas there was no difference in LH concentration at 6 and 10 weeks of age between the lines. At 14 and 20 weeks, however, the concentrations of LH were greater in the $H$ than $L$ line lambs $(P<0.05)$. After hemicastration at 6 weeks of age, the rate of growth of the remaining testis in the $\mathrm{L}$ line lambs was significantly faster than in entire lambs of that line from 10 to 20 weeks $(P<0.05$ at 10 weeks to $P<0.001$ at 20 weeks). There was no difference in the rate of testis growth between the entire and hemicastrated lambs from the $\mathrm{H}$ line from 6 to 12 weeks of age.

It can be concluded that there is an underlying genetic difference in pituitary gland and/or hypothalamic activity in ram lambs from the two selected lines.
\end{abstract}

\section{Introduction}

It has been postulated by Land (1973) that selection for a reproductive trait in the male could alter reproductive performance in the female and vice versa. This hypothesis was supported by Islam, Hill \& Land (1976) who showed that in lines of mice selected for increased ovulation rate, male offspring had increased testis size. Conversely, genetic selection for testis size in the male was subsequently found to change fertility in the female.

The change in testis size after selection for ovulation rate in Finnish Landrace sheep (Hanrahan \& Quirke, 1982) and litter size (Knight, 1984) gives support to the hypothesis that the same genes were responsible for variation in gonadal activity in both sexes (Hanrahan \& Quirke, 1982). However, other studies in sheep, for example that of Ricordeau, Blanc \& Bodin (1984), show gonadal activity in the two sexes to be genetically independent. In addition, testis growth is similar in Merino rams with or without the single high prolificacy Booroola allele (Bindon, 1984). Selection for ovulation rate in the pig indicated a positive genetic correlation (Schinckel, Johnson, Pumfrey \& Zimmerman, 1983), boars from the high ovulation rate line having testes $9-15 \%$ heavier than controls.

The development of a practical criterion for the presence of alleles which have a favourable effect on female reproductive performance, but which could be measured in a male, would potentially double the rate of response to genetic selection (Walkley \& Smith, 1980). The possibility that juvenile testis size might be such a useful criterion is being assessed by measuring the reproductive performance of lines of sheep selected for testis size (Land, Carr \& Lee, 1980). While the number of 
lambs born per female has increased in the line selected for large testes, the change in the number of eggs shed has been small while other traits such as the onset of breeding season and female fertility have changed even though they were not expected to do so (Lee \& Land, 1984).

To achieve a better understanding of genetic variation in the physiological processes underlying reproductive traits, the physiological response to the selection of sheep for juvenile testis size has been investigated in terms of both the endocrine control of testis growth and the effect of the testes on body growth and seasonal changes in body weight.

\section{Materials and Methods}

Animals. The study was carried out on ram lambs of the Finn-Dorset strain previously selected phenotypically into two lines for high $(\mathrm{H})$ and low $(\mathrm{L})$ juvenile testis diameter. Selection was based on testis diameter at 6,10 and 14 weeks of age adjusted for body weight by regression analysis at each age. Divergent lines selected for large and small testes were formed and selection among males has continued within the lines for 9 years (Land et al., 1980). Throughout the experiment, all animals were maintained under identical conditions. During the sampling periods they were housed under natural lighting conditions and had access to food and water ad libitum; the rest of the time they were kept outside on grass with supplementary feed as required for normal husbandry.

Experimental design. Ram lambs born to females of the high $(\mathrm{H})$ and low $(\mathrm{L})$ lines were allocated in rotation within lines from birth into the following experimental groups: Group 1, intact males ( $\mathrm{H}$ line, 15 animals; $\mathrm{L}$ line, 12 animals); Group 2, males castrated before 7 days of age ( $\mathrm{H}$ line, 12 animals; L line, 8 animals); Group 3, males hemicastrated at 6 weeks of age (H line, 12 animals; $L$ line, 8 animals).

Testis size and body weight were recorded every 2 weeks from 6 to 20 weeks of age in Groups 1 and 3, body weight only being measured in Group 2. Subsequently, these measurements were continued for all animals in Groups 1 and 2 on a specific occasion, irrespective of age, at 4-week intervals from 24 to 76 weeks. Testis growth was assessed in terms of the rate of change of diameter, measured along the anterior-posterior axis and including two thicknesses of scrotal skin.

Blood samples were collected at hourly intervals for $5 \mathrm{~h}$ at 6,14 and 20 weeks of age from all animals in Groups 1 and 2. At 10 weeks of age, the same groups were blood sampled at 20-min intervals for $5 \mathrm{~h}$. The plasma was separated and stored at $-20^{\circ} \mathrm{C}$ before assay for FSH, $\mathrm{LH}$ and testosterone. No blood samples were collected from Group 3 as the purpose of these animals was to determine the extent to which testis growth was restricted by negative feedback in the two lines.

Hormone assays. Peripheral plasma LH concentrations were measured using a modified doubleantibody radioimmunoassay described previously (Martensz, Baird, Scaramuzzi \& Van Look, 1976; Webb, Baxter, Preece, Land \& Springbett, 1985). FSH was assayed using a heterologous radioimmunoassay (McNeilly, McNeilly, Walton \& Cunningham, 1976). Sequential samples from all animals were measured in a single assay to avoid inter-assay variation between sampling occasions. The sensitivity of the assays was $0.5 \mathrm{ng}$ (NIH-LH-S18)/ml and $12.6 \mathrm{ng}$ (NIH-FSH$\mathrm{S} 10) / \mathrm{ml}$. The intra- and inter-assay coefficients of variation were $6 \cdot 2$ and $11 \cdot 8 \%$ and $9 \cdot 1$ and $12 \cdot 1 \%$ for $\mathrm{LH}$ and FSH respectively.

After solvent extraction testosterone was measured in a double-antibody radioimmunoassay using a sheep anti-testosterone antiserum (raised in a sheep against testosterone-3-carboxymethyloxime; Land, Morris, Baxter, Fordyce \& Forster, 1982) and ${ }^{125}$ I-labelled testosterone-3carboxymethyl-oxime-histamine (kindly supplied by Dr G. D. Nordblom, University of Michigan, U.S.A.). The assay only cross-reacts significantly with $5 \alpha$-dihydrotestosterone $(12 \cdot 1 \%)$ and 
androsterone $(3 \cdot 3 \%)$. All other steroids tested showed $<0.01 \%$ cross-reaction. Recovery of testosterone $(10-200 \mathrm{pg})$ added to ovine plasma was $81.4 \%$ (C.V. $=0.04 \% ; n=160)$. The sensitivity of the method was $0.05 \mathrm{ng} / \mathrm{ml}$ and the intra- and inter-assay coefficients of variation were 4.9 and $7 \cdot 2 \%$ respectively.

Statistical methods. All data on hormone levels were converted to logarithms before analysis. Mean levels were compared by Student's $t$ tests. The definition of a pulse and the calculation of the amplitudes of all such pulses has been described in detail by Webb et al. (1985). The regressions of testis growth on age and body weight were calculated using Harvey's least squares programme (Harvey, 1966). The differences between slopes were compared by F-tests.

\section{Results}

\section{Testis and body weight}

The mean testis sizes for the ram lambs in Group 1 are shown in Fig. 1(b) and the mean body weight for the entire and castrated animals in each line in Fig. 1(a). For analysis, the growth period was divided into four stages. The first stage was from 6 to 14 weeks which represents growth in the period equivalent to the selection criterion of the divergent lines. The second period was from 14 weeks to the date equivalent to the beginning of the breeding season in the adult females. At this time, the lambs were, on average, 20 weeks old. The third period represents the female breeding season (Days 240-443; September to March) when the lambs were $24-48$ weeks of age. The fourth period was from the onset of anoestrus to the end of the experiment, covering an age range of 52-68 weeks. Regression analyses to compare testis growth in relation to age and to body weight in the two lines were carried out for each of the 4 periods. Table 1 gives the pooled within-animal regression coefficients for each line and period and the significance of the between-line differences at each period.

In the periods ( 1 and 2 ) up to the start of the first breeding season ( 20 weeks of age), the testes of the $\mathrm{H}$ line lambs grew significantly faster $(P<0.001)$ than did those of the $\mathrm{L}$ line up to 14 weeks, but between 14 and 20 weeks the testes of the $\mathrm{L}$ line lambs grew significantly faster $(P<0.001)$. Testis size was similar in the two lines at 20 weeks. During the following period ( $24-48$ weeks) testis size decreased in both lines with no significant between-line differences. However, during seasonal anoestrus (52-68 weeks), testis size increased with age, with testes of $L$ line lambs growing faster $(P<0.05)$ (Table 1). Figure 1(a) shows that body weight increased more rapidly in the periods outside the breeding season (up to 20 weeks and between 52 and 68 weeks) than in the breeding season. The between-line difference increased with age.

Castration had a different effect on body weight in the two selection lines. In the $\mathrm{L}$ line, the castrated lambs were mostly $2-4 \mathrm{~kg}$ lighter than entire lambs from 10 to 32 weeks of age. However, these differences were only significant at $28(P<0.01)$ and $32(P<0.05)$ weeks. Although not statistically significant, castrated animals in the $\mathrm{H}$ line were generally about $2 \mathrm{~kg}$ heavier from 10 to 28 weeks, after which there was no difference in weight between the entire and castrated animals.

After hemicastration at 6 weeks of age (Group 3), the growth of the remaining testis in the $\mathrm{H}$ line lambs was similar to the mean testis growth of entire $H$ line lambs from 6 to 12 weeks of age (Fig. 1c). From 14 to 20 weeks of age, the remaining testis in the $\mathrm{H}$ line animals grew significantly faster than that in entire animals of this line $(P<0.01)$. However, testis growth in the L line hemicastrated lambs was significantly faster than that in the entire $L$ line lambs from 10 to 20 weeks, the difference in diameters being significant at all 4 sampling times $(P<0.05$ at 10 weeks, $P<0.05$ at 12 weeks, $P<0.01$ at 16 weeks and $P<0.01$ at 20 weeks). There was no significant difference between lines in the rate of growth of the remaining testis from 6 to 12 weeks. At 14 weeks of age, the remaining testis of $\mathrm{H}$ line lambs was significantly bigger than that in $\mathrm{L}$ line lambs $(P<0.05)$. 

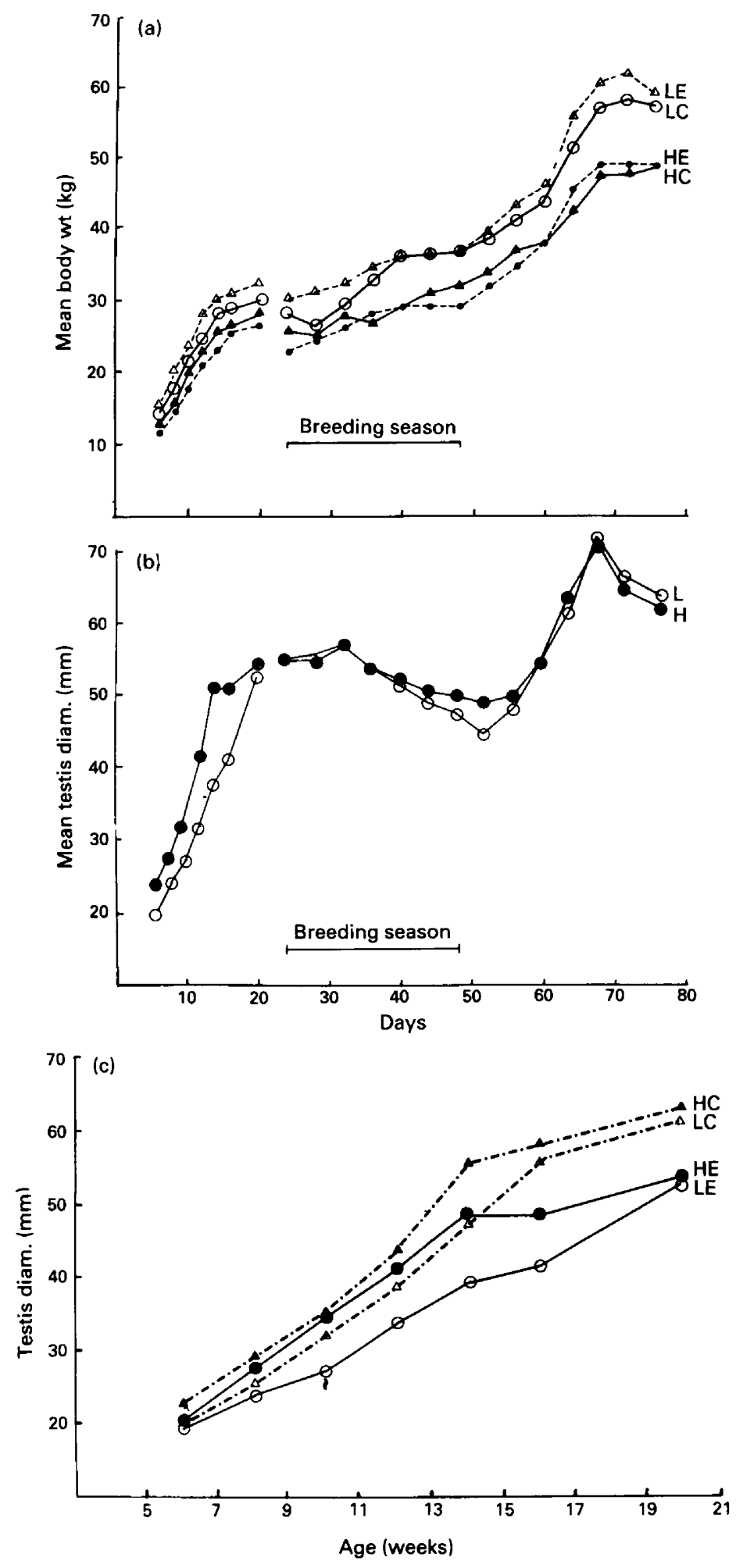

Fig. 1. (a) The mean body weight in entire and castrated ram lambs (HE, $H$ line entire; HC, $H$ line castrate: LE, L line entire; $L C$, $L$ line castrate), (b) testis diameter in entire ram lambs from the $\mathrm{H}$ and $\mathrm{L}$ selected lines and (c) testis diameter in ram lambs that had been hemicastrated at 6 weeks of age. 
Table 1. Growth of the testes of the high $(\mathrm{H})$ and low $(\mathrm{L})$ line lambs in relation to age and body weight with the significance of the difference of the regression coefficients at each period

\begin{tabular}{|c|c|c|c|c|}
\hline & $\begin{array}{l}\text { June-July } \\
\text { (selection) }\end{array}$ & $\begin{array}{c}\text { July-August } \\
\text { (pre-breeding } \\
\text { season) }\end{array}$ & $\begin{array}{l}\text { October-March } \\
\text { (breeding } \\
\text { season) }\end{array}$ & $\begin{array}{l}\text { April-July } \\
\text { (seasonal } \\
\text { anoestrus) }\end{array}$ \\
\hline $\begin{array}{l}\text { Age (weeks) } \\
\text { Regression on age }\end{array}$ & $6-14$ & $14-20$ & $24-48$ & $52-68$ \\
\hline $\begin{array}{l}\mathrm{H} \\
\mathrm{L}\end{array}$ & $\left.\begin{array}{l}+0.321 \\
+0.228\end{array}\right\} * * *$ & $\left.\begin{array}{l}0.076 \\
0.249\end{array}\right\} * * *$ & $\begin{array}{l}-0.032 \\
-0.042\end{array}$ & $\left.\begin{array}{l}+0 \cdot 164 \\
+0 \cdot 184\end{array}\right\} *$ \\
\hline \multicolumn{5}{|l|}{$\begin{array}{l}\text { Regression on } \\
\text { bodyweight }\end{array}$} \\
\hline $\begin{array}{l}\mathrm{H} \\
\mathrm{L}\end{array}$ & $\left.\begin{array}{l}+0.242 \\
+0.122\end{array}\right\} * * *$ & $\begin{array}{l}+0.076 \\
+0.250\end{array}$ & $\begin{array}{l}-0.052 \\
-0.080\end{array}$ & $\left.\begin{array}{l}+0.158 \\
+0.129\end{array}\right\} * * *$ \\
\hline
\end{tabular}

${ }^{*} P<0.05 ;{ }^{* * *} P<0.001$.

\section{Luteinizing hormone}

The plasma LH concentrations in entire and castrated ram lambs (Groups 1 and 2) collected hourly for $5 \mathrm{~h}$ at $6,10,14$ and 20 weeks of age are shown in Fig. 2. In the entire animals, there were no differences in mean values at any of the four sampling periods $(P<0.05)$. The more frequent sampling over a $5 \mathrm{~h}$ period at 10 weeks of age demonstrated that all lambs in the $\mathrm{L}$ line (12/12) and only 11 of 15 in the $\mathrm{H}$ line were releasing $\mathrm{LH}$ in a pulsatile pattern as defined by Webb et al. (1985) (Table 2). In entire animals, the amplitude of the LH pulses was greater in the lambs of the $\mathrm{L}$ than the $\mathrm{H}$ line $(P<0.01)$. The frequency of pulses was, however, the same in the two lines. The apparently lower mean concentration in the $\mathrm{H}$ line lambs at 10 weeks may therefore be meaningful despite not being significantly different. In the castrated animals, mean levels of plasma LH were similar in both $\mathrm{H}$ and $\mathrm{L}$ lines at 6 and 10 weeks of age, but at 14 and 20 weeks, there were significantly higher levels in the $\mathrm{H}$ line (Fig. $2 \mathrm{~b} ; P<0.05$ ). At 10 weeks of age, $\mathrm{LH}$ was released in pulses of high amplitude and low frequency in the $\mathrm{L}$ line but in very frequent pulses of low amplitude in the $\mathrm{H}$ line (Figs $2 \mathrm{~d} \& 2 \mathrm{c}$, respectively).

\section{Follicle-stimulating hormone}

In the entire animals, there was no difference in mean plasma FSH concentrations at 8 and 10 weeks between the two lines (Fig. 3a). However, at 14 and 20 weeks of age, FSH values in the low $\mathrm{L}$ line animals were significantly greater than in the $\mathrm{H}$ line $(P<0.01)$. By contrast to the relatively similar concentrations in the entire animals of the two lines, FSH concentrations in the $\mathrm{H}$ line animals were significantly greater $(P<0.001)$ than those in the $\mathrm{L}$ line at all sampling periods in the castrates (Fig. 3b).

\section{Testosterone}

Figure 4 shows the mean concentrations of testosterone in the $\mathrm{H}$ and $\mathrm{L}$ selected ram lambs. While the $\mathrm{H}$ line lambs produced higher mean values of testosterone than did those of the $\mathrm{L}$ line in samples collected at hourly intervals throughout the experimental period, these were not significantly different, probably because of the pulsatile pattern of testosterone release, with consequent large variations in concentration. 

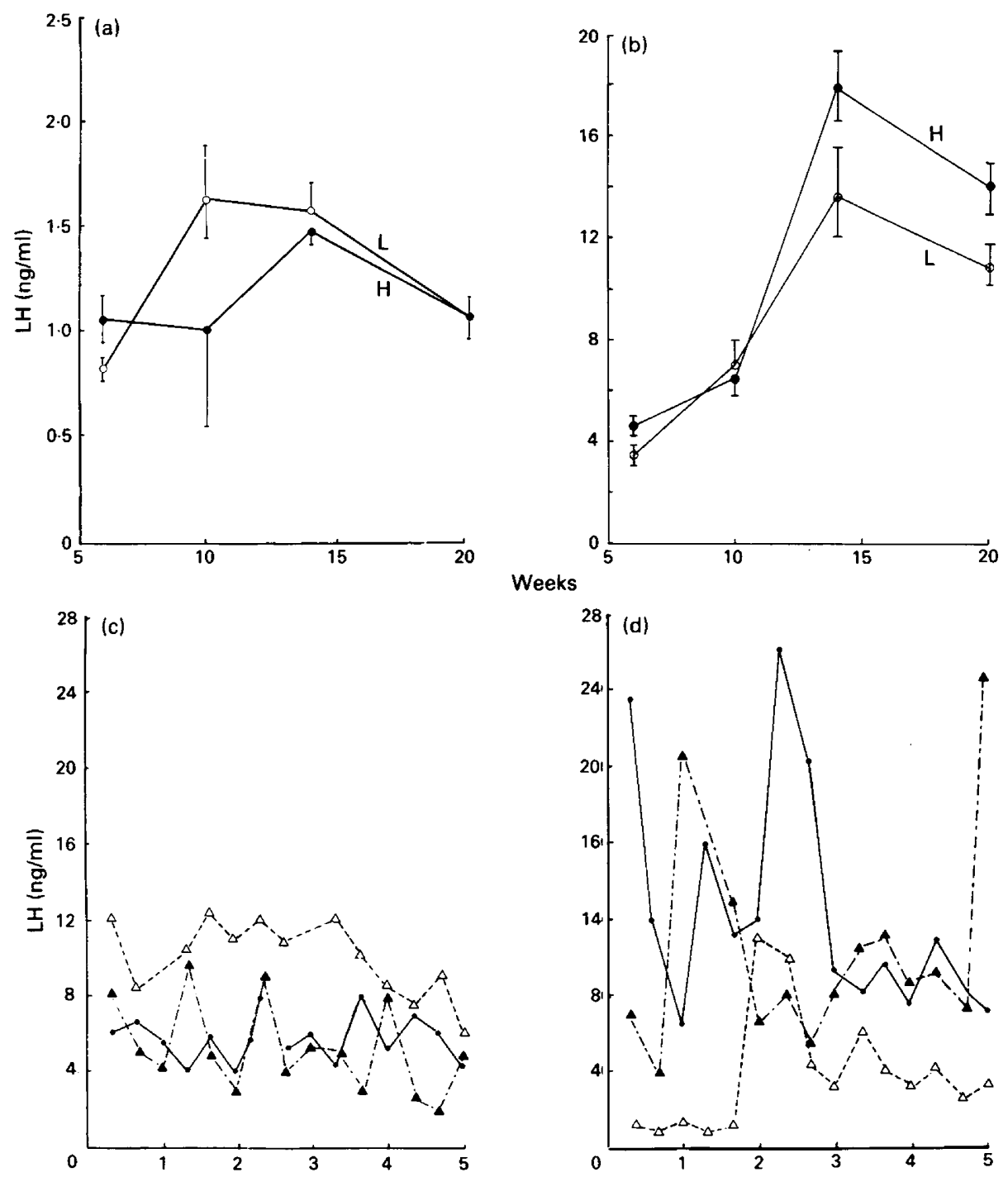

Hours

Fig. 2. Mean \pm s.e.m. plasma LH concentrations in (a) entire and (b) castrated ram lambs from the two selected lines, $\mathrm{H}$ and $\mathrm{L}$. Plasma $\mathrm{LH}$ concentrations in 3 individual castrated ram lambs from the $\mathrm{H}$ and $\mathrm{L}$ lines in samples collected over a 5 -h period at 10 weeks of age are shown in (c) and (d) respectively.

\section{Discussion}

Selection on the basis of testis size in young Finn-Dorset ram lambs has caused two divergent lines to be established with not only an alteration in the rate of testis growth, but also changes in the rate of body growth. Ram lambs from the $\mathrm{H}$ selected line had testes which reached the maximum size during the first year of age, about 6 weeks before the lambs from the $L$ line. This indicates that selection has favoured a faster developing although not a larger mature gonad as testis size was similar for the 2 lines by 20 weeks of age. As a consequence of this, body weight appears to be 
Table 2. LH pulse frequency and amplitude in entire and castrated ram lambs from the lines selected for high $(\mathrm{H})$ and low $(\mathrm{L})$ testis growth

\begin{tabular}{lccc}
\hline Group & $\begin{array}{c}\text { No. animals } \\
\text { showing pulsatile } \\
\text { LH release }\end{array}$ & $\begin{array}{c}\text { Mean no. } \\
\text { of pulses/ } \\
\text { animal/5 }\end{array}$ & $\begin{array}{c}\text { Mean } \\
\text { amplitude } \\
(\mathrm{ng} / \mathrm{ml})\end{array}$ \\
\hline $\begin{array}{l}\text { 1, high (H), } \\
\text { entire }\end{array}$ & $11 / 15$ & 1.45 & $6 \cdot 58^{\mathrm{a}}$ \\
$\begin{array}{l}\text { 2, low (L), } \\
\text { entire }\end{array}$ & $12 / 12$ & 1.5 & $8 \cdot 56^{\mathrm{b}}$ \\
$\begin{array}{l}\text { 3, high (H), } \\
\text { castrated }\end{array}$ & $10 / 10$ & $-*$ & $-\mathbf{*}^{*}$ \\
$\begin{array}{l}\text { 4, low (L), } \\
\text { castrated }\end{array}$ & $6 / 7$ & $2 \cdot 5$ & $9 \cdot 5^{\mathrm{c}}$ \\
\hline
\end{tabular}

* Amplitude too low for analysis.

a-b, $P<0.01 ;$ a-c, $P<0.01 ; b-c$, N.S.

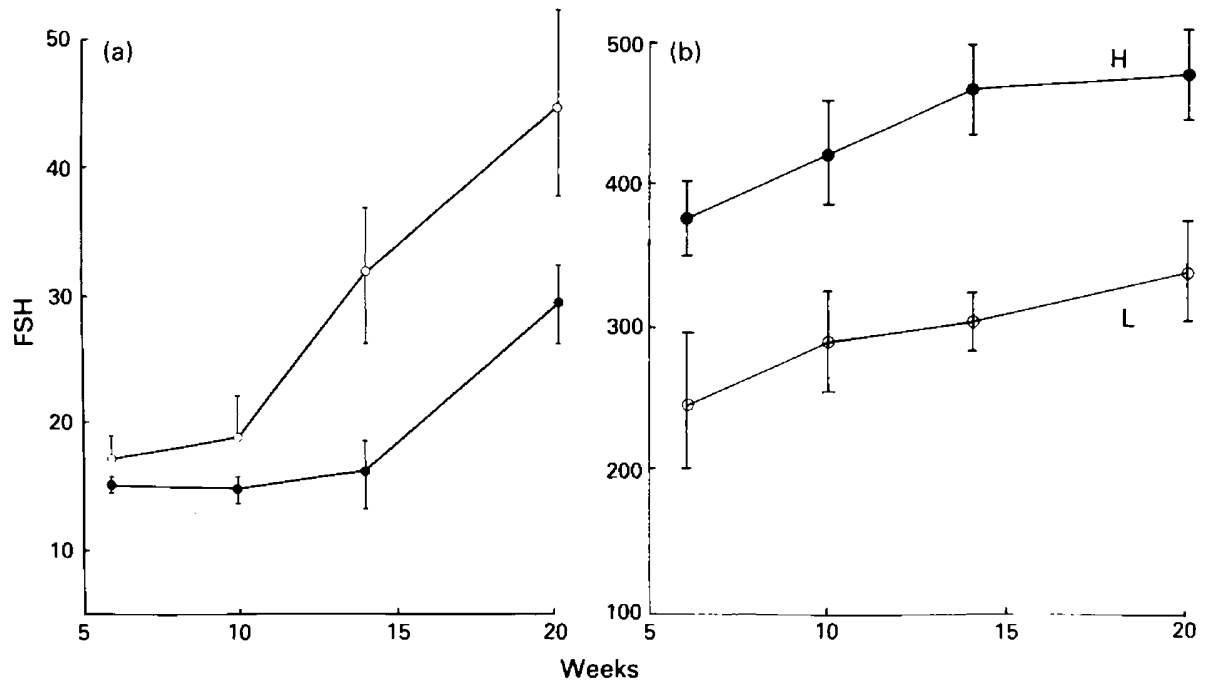

Fig. 3. Mean \pm s.e.m. plasma FSH concentrations in (a) entire and (b) castrated lambs from the 2 selected lines, $\mathrm{H}$ and $\mathrm{L}$.

retarded so that, by 72 weeks of age, $\mathrm{H}$ line rams are about $10 \mathrm{~kg}$ smaller than those of the $\mathrm{L}$ line. In addition, after castration, ram lambs in the $\mathrm{H}$ line were heavier from 6 to 28 weeks of age, suggesting that in this line the gonads and hence gonadal products are restricting body growth. Perhaps the $\mathbf{H}$ line lambs are more sensitive to higher levels of gonadal steroids at an earlier age than are those of the $L$ line and that the rate of body growth throughout puberty is influenced by hormone levels during the first 6 weeks of life. Further investigations are being carried out on the selected lines from birth to 6 weeks of age.

Conversely, in boars selected phenotypically on the basis of testis size, the mature animals with the larger testes were significantly heavier (Schinckel, Johnson \& Kittok, 1983). Therefore, although both boars and ram lambs were selected on testis size, the faster developing testis, proportional to body size, in the ram lambs could have significantly retarded the rate of body growth. 


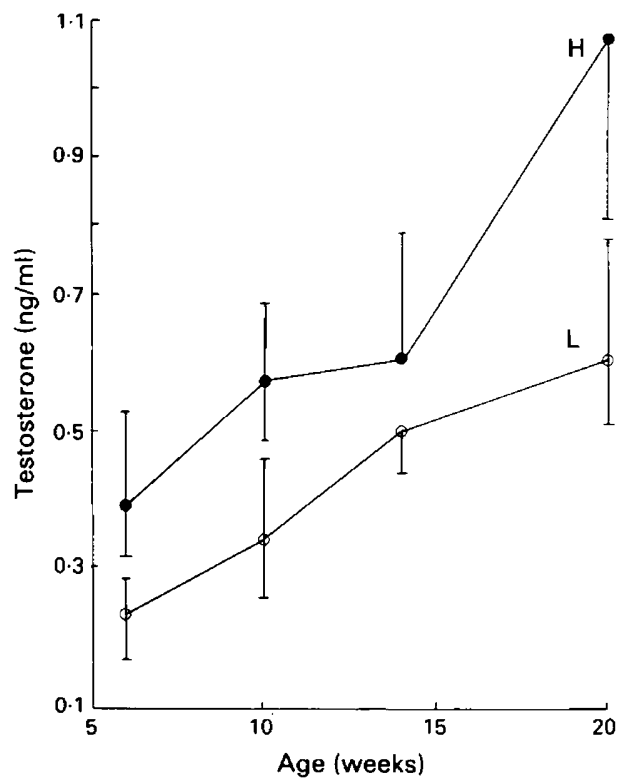

Fig. 4. Mean \pm s.e.m. plasma testosterone concentrations in entire ram lambs from the 2 selected lines, $\bar{H}$ and $\mathrm{L}$.

Differences in both testis size and body weight were already significant by 6 weeks of age, when the testis is relatively immature (Carmon \& Green, 1952; Schanbacher, Gomes \& VanDemark, 1974). It is not known when these differences can first be detected or whether there are significant differences in testes size and body growth at birth. However these differences in body growth were similar in the castrates, indicating that the rate of growth has been changed directly as a consequence of the selection criterion rather than as a result of changes in anabolic steroids from the rapidly developing gonads. Furthermore, the steroid concentrations of the anabolic steroid testosterone in the entire lambs were, if anything, lower in the more rapidly growing L lambs, though not statistically so.

After hemicastration, the growth of the remaining testis in lambs of the $\mathbf{H}$ selected line was similar to the mean testis growth in the entire $\mathrm{H}$ line animals from 6 to 12 weeks of age, indicating that testis growth within the $\mathrm{H}$ line was at a maximum. In contrast, testis growth in the entire $\mathrm{L}$ line animals appeared to be restricted, probably by the feedback effect of gonadal steroids as hemicastration causes a rapid increase in the rate of growth in the remaining testis. This pattern of testis growth is in agreement with data of Waites, Wenstrom, Crabo \& Hamilton (1983) who observed that hemicastration within 7 days of birth caused the remaining testis to increase rapidly in size up to 12 weeks of age. The $\mathrm{H}$ line, which had the greater rate of testis growth showed the lesser response to hemicastration; this agreed with the response to hemicastration in breeds with a naturally greater rate of testis growth (Land \& Carr, 1975).

Mean gonadotrophin and testosterone concentrations were similar at 6 and 10 weeks of age in the entire ram lambs despite differences in testis size. The patterns of pulsatile $\mathrm{LH}$ release in the two lines were also similar at these ages and are in agreement with those observed by Foster et al. (1978) in entire ram lambs at 8 weeks of age. When the $\mathrm{H}$ line testis was growing most rapidly between 10 and 14 weeks of age, FSH secretion was significantly lower than in the $\mathbf{L}$ line animals, possibly due to the negative feedback of increasing levels of gonadal steroids and inhibin (Blanc \& Terqui, 1976). However, even when the $\mathrm{L}$ line testis growth was at a maximum, the negative feedback effect of gonadal products did not depress the FSH levels to that of the $\mathrm{H}$ line. This therefore raises the question as to the importance of small changes in FSH concentrations in the control of testis growth. At 
14 and 20 weeks of age, decreasing photoperiod was probably exerting an effect on gonadotrophin concentrations. In previous studies (Lincoln, Peet \& Cunningham, 1977; Lincoln, 1979), FSH concentrations and testis size rose in response to shortening daylength.

Pulsatile secretion of $\mathrm{LH}$ at 10 weeks of age in the castrated $\mathrm{H}$ line ram lambs demonstrated the inherent ability of the hypothalamus to generate the rapid pulse frequency and low-amplitude pattern observed by Foster et al. (1978) in prepubertal ram lambs and by Schanbacher \& D'Occhio (1984), in mature castrated rams. A similar pattern of LH release has also been shown in entire rams kept in short daylengths ( $8 \mathrm{~h}$ light:16 h dark) by Lincoln (1978). In contrast, the pattern of pulsatile $\mathrm{LH}$ secretion in the castrated $\mathrm{L}$ line animals at 10 weeks of age was typical of entire rams on a long-day photoperiod (high amplitude, low frequency) when there is little or no testis growth. Whether the pattern of $\mathrm{LH}$ pulsatile release in the $\mathrm{L}$ line animals will change to the more frequent, low-amplitude pattern at 14 weeks of age when testis growth in the entire animals of this line would be at a maximum is not known. It is possible that the LHRH pulse generator is less sensitive to changes in photoperiod at 10 weeks of age in the $\mathrm{L}$ line lambs than in those of the $\mathrm{H}$ line. However, D'Occhio, Schanbacher \& Kinder (1984) found differences in LH pulsatility between breeds in mature rams during short daylengths when there was rapid testis growth.

In conclusion, the $\mathrm{H}$ line ram lambs are faster maturing than those in the $\mathrm{L}$ line which ultimately leads to a significantly smaller adult size although there are no differences in mature testis size. The present investigation demonstrates an inherent difference in hypothalamic/pituitary activity controlling FSH release which is already established by 6 weeks of age.

We thank Mr D. McBride and the farm staff for excellent technical assistance; Ms A. J. Springbett for statistical advice; Mrs J. Cherrie for typing the manuscript; Mr J. C. Manson for art work; NIAMDD and Dr M. Jutisz for hormone preparations; and Dr S. S. Lynch for the FSH antiserum.

\section{References}

Bindon, B.M. (1984) Reproductive biology of the Booroola Merino sheep. Aust. J. biol. Sci. 37, 163-189.

Blanc, M.R. \& Terqui, M. (1976) Determination of the age of establishment of the inhibin-follicle-stimulating hormone feedback mechanism in the ram lamb. IRSC Med. Sci. 4, 17.

Carmon, J.L. \& Green, W.W. (1952) Histological study of the development of the testis of the ram. J. Anim. Sci. 11, 674-687.

D'Occhio, M.J., Schanbacher, B.D. \& Kinder, J.E. (1984) Profiles of luteinizing hormone, follicle-stimulating hormone, testosterone and prolactin in rams of diverse breeds: effects of contrasting short (8L:16D) and long (16L:8D) photoperiods. Biol. Reprod. 30, 1039-1054.

Foster, D.L., Mickelson, I.H., Ryan, K.D., Coon, G.A., Drongowski, R.A. \& Holt, J.A. (1978) Ontogeny of pulsatile luteinising hormone and testosterone secretion in male lambs. Endocrinology 102, 1137-1146.

Hanrahan, J.P. \& Quirke, J.F. (1982) Selection on ovulation rate in sheep aided by the use of superovulation and egg transfer. In Proc. Wld Congr. Sheep and Beef Cattle Breeding, pp. 329-335. Eds R. A. Barton \& W. C. Smith. Dunmore Press Ltd, Palmerston North.

Harvey, W.R. (1966) Least squares analysis of data with unequal subclass numbers. USDA-ARS 20, 1-157.
Islam, A.B.M.M., Hill, W.G. \& Land, R.B. (1976) Ovulation rate of lines of mice selected for testes weight. Genet. Res. 27, 23-32.

Knight, T.W. (1984) Testicular growth and size in rams from flocks of different reproductive potential. N.Z. J. agric. Res. 27, $179-187$.

Land, R.B. (1973) The expression of female sex-limited characters in the male. Nature, Lond. 241, 208-209.

Land, R.B. \& Carr, W.R. (1975) Plasma luteinizing hormone levels and testis diameters of ram lambs of different breeds. J. Reprod. Fert. 42, 325-333.

Land, R.B., Carr, W.R. \& Lee, G.J. (1980) A consideration of physiological criteria of reproductive merit in sheep. In Selection Experiments in Laboratory and Domestic Animals, pp. 147-160. Ed. A. Robertson. Commonwealth Agricultural Bureaux, Farnham.

Land, R.B., Morris, B.A., Baxter, G., Fordyce, M. \& Forster, J. (1982) Improvement of sheep fecundity by treatment with antisera to gonadal steroids. $J$. Reprod. Fert. 66, 625-634.

Lee, G.J. \& Land, R.B. (1984) Testis size and LH response to LH-RH as male criteria of female reproductive performance. In Genetics of Reproduction in Sheep, pp. 333-341. Eds R.B. Land \& D.W. Robinson. Butterworths, London.

Lincoln, G.A. (1978) The temporal relationship between plasma levels of FSH and LH in the ram. J. Reprod. Fert. 52, 427-436. 
Lincoln, G.A. (1979) Photoperiodic control of seasonal breeding in the ram: participation of the cranial sympathetic nervous system. J. Endocr. 82, 135-147.

Lincoln, G.A., Peet, M.J. \& Cunningham, R. (1977) Seasonal and circadian changes in the episodic release of follicle-stimulating hormone, luteinizing hormone and testosterone in rams exposed to artificial photoperiods. J. Endocr. 72, 337-349.

Martensz, N.A., Baird, D.T., Scaramuzzi, R.T. \& Van Look, P.F.A. (1976) Androstenedione and the control of luteinizing hormone in the ewe during anoestrus. J. Endocr. 69, 227-237.

McNeilly, J.R., McNeilly, A.S., Walton, J.S. \& Cunningham, F.J. (1976) Development and application of a heterologous radioimmunoassay for ovine follicle-stimulating hormone. J. Endocr. 70, 69-79.

Ricordeau, G., Blanc, M.R. \& Bodin, L. (1984) Teneurs plasmatiques en FSH et LH des agneaux males et femelles issus de bèliers Lacaune prolifiques et non prolifiques. Gènèt. Sèl. Evol. 16, 195-210.

Schanbacher, B.D. \& D'Occhio, M.J. (1984) Hypothalamic control of the post-castration rise in serum LH concentration in rams. J. Reprod. Fert. 72, $537-542$.

Schanbacher, B.D., Gomes, W.R. \& VanDemark, N.L. (1974) Developmental changes in spermatogenesis, testicular carnitine acetyl transferase activity and serum testosterone in the ram. J. Anim. Sci. 39, 889-892.
Schinckel, A.P., Johnson, R.K. \& Kittok, R.J. (1983) Testicular development and endocrine characteristics of boars selected for either high or low testis size. $J$. Anim. Sci. 58, 675-685.

Schinckel, A.P., Johnson, R.K., Pumfrey, R.A. \& Zimmerman, D.R. (1983) Testicular growth of different genetic lines and its relationship to reproductive performance. J. Anim. Sci. 56, 1065-1076.

Waites, G.M.H., Wenstrom, J.C., Crabo, B.G. \& Hamilton, D.W. (1983) Rapid compensatory hypertrophy of the lamb testis after neonatal hemiorchidectomy: endocrine and light microscopical morphometric analyses. Endocrinology 112, 2159-2167.

Walkley, J.R.W. \& Smith, C. (1980) The use of physiological traits in genetic selection for litter size in sheep. J. Reprod. Fert. 59, 83-88.

Webb, R., Baxter, G., Preece, R.D., Land, R.B. \& Springbett, A.J. (1985) Control of gonadotrophin release in Scottish Blackface and Finnish Landrace ewes during seasonal anoestrus. J. Reprod. Fert. 73, $369-378$. 